\title{
Research on financial reporting by defined benefit schemes
}

\author{
WORKING PAPER SERIES \\ Working Paper no. 45 \\ 2007
}

\section{Rachel F. Baskerville}

Associate Professor, School of Accounting and Commercial Law Victoria University of Wellington, P O Box 600, Wellington, New Zealand

Email: rachel.baskerville@vuw.ac.nz

Tel: $++(64)(4) 4636474$

Fax: ++(64)(4) 4635076

Centre for Accounting, Governance and Taxation Research

School of Accounting and Commercial Law

Victoria University of Wellington

PO Box 600

Wellington

NEW ZEALAND

Tel. +6444635078

Fax. + 6444635076

http://www.vuw.ac.nz/sacl/research/CAGTR/CAGTRhomepage.aspx 


\title{
Research on financial reporting by defined benefit schemes
}

\author{
Rachel F. Baskerville
}

2006

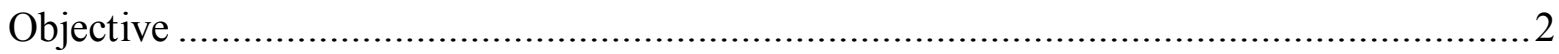

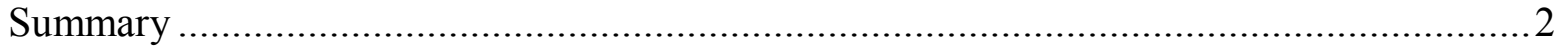

Part 1: Background .................................................................................................. 3

Data from the Annual Reports to Parliament by the Government Actuary ........................ 4

International Standards ................................................................................ 7

Compliance with FRS-32 Financial Reporting by Superannuation Schemes...................... 9

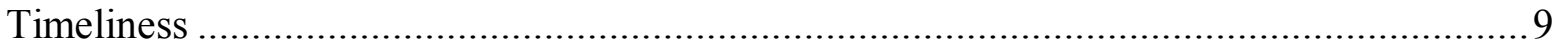

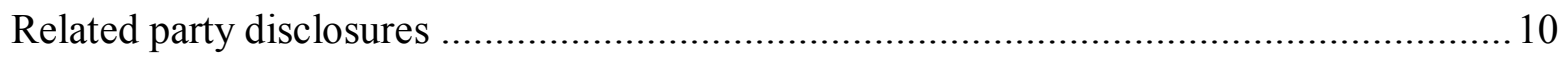

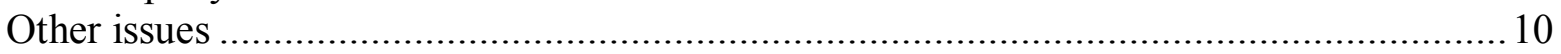

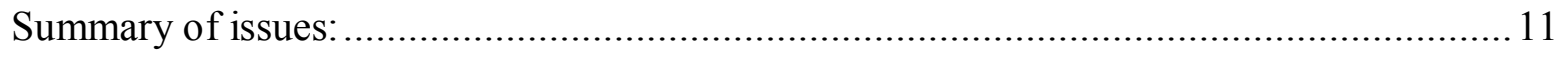

Part 2: Funding levels of superannuation schemes in New Zealand ................................ 12

Is such information useful to shareholders of the sponsoring entity? .............................. 13

Contribution holidays not taken as often as expected............................................ 13

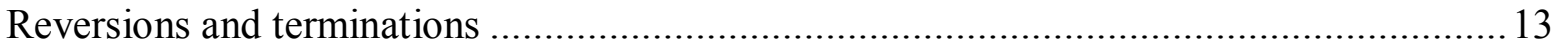

Part 3: Listed company disclosures in New Zealand............................................... 17

Research concerning the market perception of the relevance of superannuation disclosures 22

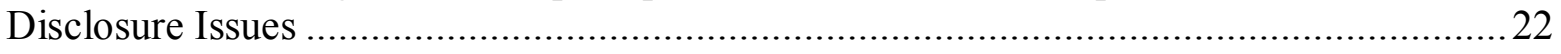

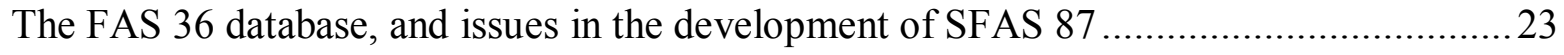

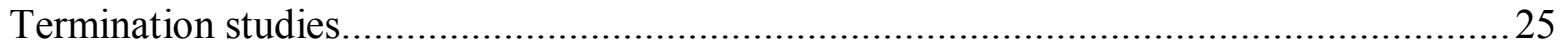

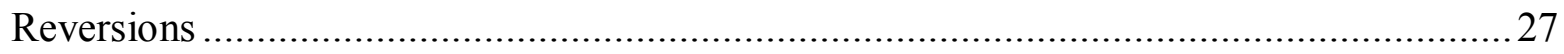

SFAS 87 Employers' Accounting for Pensions ...................................................... 27

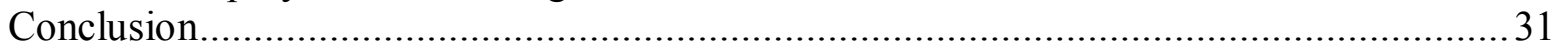

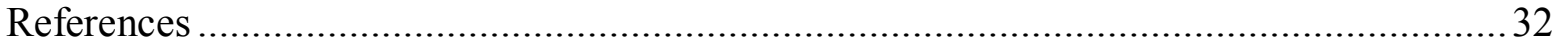




\section{Objective}

The objective of this working paper is to provide a comprehensive, readable and informative summary of superannuation reporting by defined benefit schemes in New Zealand; in order to:

- monitor compliance with FRS 32 and identify areas where further requirements or amendments may be beneficial to users of such scheme reports; and

- gain information with which an interested individual may be able to evaluate the necessity for a reporting standard addressing the reporting of superannuation schemes assets and liabilities by sponsoring entities; or in other ways to encourage adequate disclosure of superannuation schemes assets and liabilities by listed companies in New Zealand.

Most of the work examining the schemes reports was undertaken in January 2000, and only one year of each scheme's reports has been examined.

\section{Summary}

- New Zealand enjoys a situation where there has been a long tradition of well-exercised supervision of defined benefit schemes by the Government Actuary.

- Because superannuation schemes open to new members are deemed issuers by virtue of the 1997 amendments to the Financial Reporting Act, such schemes have to file their financial statements at the Companies Office, making it is easier to evaluate reporting by such entities. 164 superannuation schemes have filed their financial statements.

- The 54 schemes that have not filed reports because they are in the process of being wound up, or are closed to new members, cannot be similarly evaluated, and there may be issues concerning surpluses or deficits in such schemes that this working paper has not considered.

- Only seven of the 164 schemes in this study show a deficit that is likely to represent a liability for the sponsoring entity.

- The sponsoring entities are taking a contribution holiday in 71 of the 164 schemes. Some entities do not take a contribution holiday when it could be expected; this suggests that sponsoring entities may use superannuation schemes as a mean of earnings management.

- 21 listed companies in New Zealand sponsor a total of 29 defined benefit schemes. There are scant disclosures by listed companies concerning scheme assets or liabilities, apart from companies complying with SFAS 87 or AASB 1028. New Zealand listed companies whose schemes are in deficit do not refer to the superannuation scheme in their annual reports. 


\section{Background}

The liquidation of surplus assets in superannuation schemes has been a recurring feature of takeover activity in other jurisdictions for many years. In an equally dramatic fashion, the scale of undisclosed liabilities in defined benefit plans continues to make headlines in the United Kingdom; such as "Firms 'massaging' figures to mask pension shortfalls" (Whitehead, 1999). It is not only in the UK where large entities have masked information about pension schemes. The Japanese government is forcing through amendments to the Securities laws that will radically change the way companies fund and disclose their pension obligations (Thornton, 1999). The Toshiba Corporation disclosed US $\$ 504$ million in unfunded pension liabilities ${ }^{1}$. The Nissan Motor Company has unfunded pension liabilities of \$US 3.3 billion, and an additional $\$ 1.5$ billion of deferred tax and pension provision liabilities to the end of March $1999^{2}$. The driver behind much pressure in the United States to incorporate pension fund fluctuations in the sponsoring entity accounts (as required since 1985 by SFAS 87 Employers' Accounting for Pension Plans) was because of undisclosed liabilities.

Superannuation schemes may have large surpluses, which are often able to move back into the books of the sponsoring entity if permitted by the Trust Deed. When the trust deed does not permit such a reversion, the issue of "to whom this surplus belongs" may end up in the Courts when companies apply for changes to superannuation scheme trust deeds to allow distributions of surplus assets to both beneficiaries and the sponsoring companies. A material surplus can also allow relief to the sponsoring company from paying employer contributions into a scheme; and employee benefit expense is reduced each year a "contribution holiday" is taken by the sponsoring company.

Since the surge in market returns in the USA in the last two years, there is now a situation where overfunded pension plans are described as "fattening" companies' earnings (Schultz, 1999a). For example, of General Electric Company's 1998 pre-tax profit of $\$ 13.8$ billion, its pension plan provided more than $\$ 1$ billion. Those same pension plans that used to be a financial burden for many US companies, and were so often under funded, have grown fat, as the stock market in which they invest has rolled on. US entities cannot withdraw (enact a reversion) of such surpluses without paying a steep excise tax, enacted in 1990 to put a stop to the pension raids of the 1980's. However, they are required by SFAS 87 to recognise the volatility of pension plan changes in their income statement.

An examination of some of the surpluses from the New Zealand data shows a similar pattern; not so much due to recent share market returns, but more reflective of a long history of conservative superannuation fund management, and continuing high returns on funds throughout the 1980's.

\footnotetext{
${ }^{1}$ Nikkei Weekly 18.1 .99

${ }^{2}$ Pension and Investment 5.4 .99 page 1.
} 
The only company in New Zealand where a credit for surpluses is taken to the income statement was Fletcher Challenge Limited, as they adopted the SFAS 87 accounting treatment. In order to examine compliance with FRS 32 and examine the existence of superannuation schemes assets and liabilities by sponsoring entities other the FCL, the first data examined were statistics in the annual reports of the Government Actuary in New Zealand.

\section{Data from the Annual Reports to Parliament by the Government Actuary}

An examination was made of the reports of the Government Actuary from 1992 - 1999. In these annual reports to Parliament the Government Actuary analyses a selection (approximately one third) of all DBSs to assess the levels of deficits or large surpluses in New Zealand DBSs. The Reports also makes one-line disclosures regarding the reversions of assets to employers, which the Government Actuary has approved in the last period. These reports are all dated 30 June, for the year ended:

\begin{tabular}{|l|l|l|l|l|l|l|}
\hline Table 1: & \multicolumn{5}{|l}{ Membership of all schemes in New Zealand } & \\
\hline & $\mathbf{1 9 9 3}$ & $\mathbf{1 9 9 4}$ & $\mathbf{1 9 9 5}$ & $\mathbf{1 9 9 6}$ & $\mathbf{1 9 9 7}$ & $\mathbf{1 9 9 8}$ \\
\hline DCS members & 214,128 & 209,649 & 207,613 & 203,622 & 198,312 & 189,833 \\
\hline DBS members & 85,916 & 83,877 & 81,639 & 77,824 & 79,202 & 76,424 \\
\hline $\begin{array}{l}\text { Total assets of } \\
\text { all schemes - }\end{array}$ & $9,294,000,000$ & $9,840,000,000$ & $9,508,000,000$ & $9,741,000,000$ & $9,865,000,000$ & $10,202,000,000$ \\
\hline $\begin{array}{l}\text { Total assets in } \\
\text { DBS - \$ }\end{array}$ & $5,985,000,000$ & $6,166,000,000$ & $6,041,000,000$ & $5,775,000,000$ & $5,795,000,000$ & $5,924,000,000$ \\
\hline No. of DBSs & 371 & & & & & \\
\hline No. of DCSs & 1,228 & 1,121 & 1,001 & 879 & 779 & 247 \\
\hline
\end{tabular}




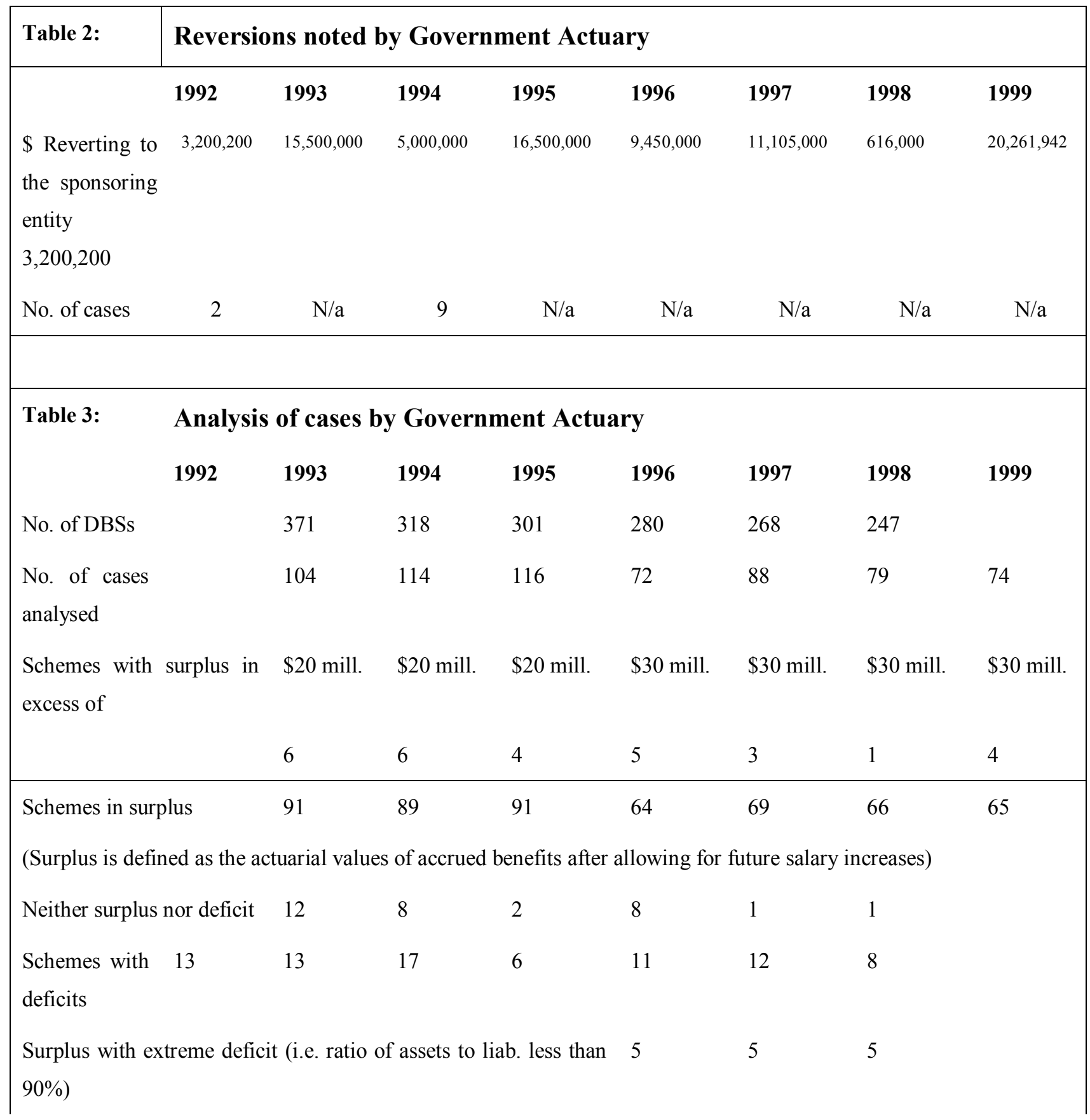

The analysis within these reports indicated that it was likely that some listed companies in New Zealand might have material undisclosed assets or liabilities. Therefore a request was made to the Government Actuary under the Official Information Act for the following information: 
1. The names of the sponsoring entities of Defined Benefit Schemes which have surplus assets in excess of $\$ 30$ million in their 1998 reports.

2. The names of the sponsoring entities of schemes which applied for a reversion of scheme assets to the sponsoring entity in 1998, and the relevant dollar amounts involved in each case.

3. The name of the eight schemes from the survey of 74 schemes in 1998 that showed an actuarial deficit.

4. The names of all defined benefit schemes that show a deficit.

The Government Actuary replied by letter of 17 November 1999 that his predecessor, Neil Malley, obtained advice from the Ombudsman that "information obtained by the Government Actuary in the administration of the Superannuation Schemes Act 1989 does not come with the ambit of the Official Information Act...”. He offered to supply the names and addresses of those superannuation schemes which were recorded as requiring what are called "section 15 reports" to be filed; i.e. the defined benefit schemes registered at his office. This list of the 257 defined benefit plans was obtained from the Government Actuary; and all of the reports available in the Companies Offices, in Auckland, Hamilton, Wellington, Christchurch, and Dunedin were examined in January 2000. Two further reports $^{3}$ were added to this list. The Companies Office provided filed reports for 164 defined benefit plans. 25 plans on the Government Actuary's list are now defined contribution plans, 38 are not required to file because they are closed to new members, and 16 are in the process of being wound up. Table 4 details superannuation schemes included in the sample.

This working paper excludes consideration of the Government Superannuation Fund. This is the largest scheme in New Zealand, with 36,347 contributors and 45,651 beneficiaries in 1998. Assets of $\$ 3,402$ billion do not cover the liabilities; the deficit is calculated at $\$ 646$ million $^{4}$. The next largest schemes (assets between \$250 - \$700 mill.) include two National Provident Fund Schemes, three schemes sponsored by banks (WestpacTrust, BNZ and National Bank) and the Fletcher Challenge scheme. None of these are in deficit.

\footnotetext{
${ }^{3}$ New Zealand Refining, Amcor

${ }^{4}$ Reuters 15.9.99
} 


\begin{tabular}{|l|l|}
\hline Table 4: 164 Superannuation schemes included in this analysis & \\
\hline Defined Benefit Plans filed at the Companies Offices & 164 \\
\hline Not filed at Companies Offices & 4 \\
\hline Defined Contribution Plans (some with defined benefit members) & 25 \\
\hline Old Government Superannuation Schemes with no members & 7 \\
\hline Government Superannuation Fund & 1 \\
\hline Closed to new members and therefore are not required to file (see page 27) & 38 \\
\hline In the process of being wound up (see page 27) & 16 \\
\hline Fletcher Challenge not included in analysis (complies with SFAS 87) & 1 \\
\hline Excluded due to double-listing or not subject to FRS-32 & 3 \\
\hline Total: & $\mathbf{2 5 9}$ \\
\hline
\end{tabular}

\section{International Standards}

FRS 32 Financial Reporting by Superannuation Schemes (1998) is paralleled by other internationals standards concerned with reporting by superannuation schemes.

- USA: SFAS 35 Accounting and Reporting by Defined Benefit Pension Plans (1980).

- United Kingdom offers a Statement of Recommended Practice Financial Reports of Pension Schemes (1996).

- International Accounting Standard 26 Accounting and Reporting by Retirement Benefit Plans (1987).

- Australian Standard AAS 25 Financial Reporting by Superannuation Schemes (1993).

In common with such overseas standards, defined benefit schemes are not required to measure liabilities every reporting period.

There are also international standards prescribing the reporting of superannuation scheme assets and liabilities in the financial reports of the sponsoring companies. These include:

- USA: SFAS 87 Employers' Accounting for Pensions (1985); this prescribes the measurement of the pension expense which has to be recognised in the performance statement. A pension

\footnotetext{
${ }^{5}$ Globus Group (NZ) Ltd Pension Plan; NZ Racing Conference Retirement Scheme; QBE NZ Staff Superannuation Plan; Reformed Churches of New Zealand Emeritus Fund
} 
liability/asset ${ }^{6}$ will be recognised in the position statement reflecting the difference between the cumulative pension expenses and the cumulative pension funding. A pension liability will also be recognised in the position statement if the present value of pension commitments exceeds the assets in the pension fund.

- United Kingdom: FRS 17 Retirement Benefits (2000). This prescribes the treatment of pensions and other retirement benefits in the employer's accounts. The new standard replaces the existing UK standard, SSAP 24 'Accounting for pension costs'. FRS 17 abandons the use of actuarial values for assets in a pension scheme in favour of a market value based approach. This is consistent with practice internationally. It is also in line with the increasing use of market values by the actuarial profession in the UK.

The use of market values at the balance sheet date introduces volatility into the measurement of the surplus or deficit in the pension scheme. The ASB has developed a distinctive approach to cope with the volatility. The performance statement shows the relatively stable ongoing service cost, interest cost and expected return on assets measured on a basis consistent with international standards. The effects of the fluctuations in market values, on the other hand, are not part of the operating results of the business and are treated in the same way as revaluations of fixed assets, i.e. are recognised immediately in the second performance statement, the statement of total recognised gains and losses (similar to the Statement of Movements in Equity). This has two advantages over the international (IAS) approach:

a) the statement of financial position shows the deficit or recoverable surplus in the scheme and

b) the total profit and loss charge is more stable than it would be if the market value fluctuations were spread forward.

Introducing FRS 17, Sir David Tweedie, now IASB Chairman, commented: "Pension cost accounting has for a long time been an impenetrable black box to users of accounts. This new standard will help all interested parties to understand the implications for a company of running a defined benefit pension scheme. It may not be popular with some who would like the present obscurity to remain but transparency of information must be preferable. It should mean that decisions about pension provision are made on a better-informed basis. In my view, the UK now has the best standard in the world for accounting for pensions and I would expect it to trigger similar reviews in other countries."

\footnotetext{
${ }^{6} \mathrm{http} / / /$ www.asb.org.uk/publications/publication306.html
} 
Links between New Zealand and the United Kingdom strengthen the usefulness of FRS 17 for two reasons: firstly, case law governing the rights of the sponsors to superannuation scheme assets and liabilities may draw on United Kingdom cases. Secondly, the United Kingdom has the Statement of Total Recognised Gains and Losses (similar to our Statement of Movements in Equity) wherein it is proposed that the volatility in liabilities or assets of schemes of the superannuation scheme should be recorded. The question is whether or not and entities in New Zealand would be permitted to recognise such movements in Statement of Movements in Equity. It appears the exemplary practice prescribed by FRS 17 in the UK may be able to be applied here further to the recent amendment to FRS $2^{7}$.

- International Accounting Standard 19 Employee entitlements (1998) - similar to SFAS 87.

- Australian Standards AASB 1028/AAS 30 Accounting for Employee Entitlements (1994). These standards did not establish measurement and recognition criteria for superannuation entitlements in financial statements, but require disclosure by way of Note. Para 14(e) requires disclosure of information for each defined benefit plan sponsored by the company, including accrued benefits, net market value of assets and vested benefits.

\section{Compliance with FRS-32 Financial Reporting by Superannuation Schemes}

FRS 32 Financial Reporting by Superannuation Schemes was introduced to apply to all superannuation schemes' financial reports after April 1, 1995. In spite of the 'fine-tuning' of the standard with some revision in 1998 (Laswad and Robertson, 1998), examination of the 164 defined benefit schemes shows that compliance with all requirements of FRS 32 Financial Reporting by Superannuation Schemes remains an issue for preparers and auditors. There is only little improvement since the 1995 study by Laswad and Baskerville. For example, 15 out of the 164 schemes did not disclose vested benefits. Four schemes did not provide an actuarial valuation for accrued liabilities, although describing the amount of a surplus (or, in once case, a deficit) in narrative. Four schemes did not provide any valuation of liability for accrued benefits.

\section{Timeliness}

A chief problem concerns the timeliness of the valuations of liabilities for accrued benefits of the schemes. It is permitted by FRS 32 that an actuarial valuation of accrued benefits can be up to three years old.

\footnotetext{
${ }^{7}$ See the Interpretation of FRS-2 para 9: "Where there is no approved FRS or existing SSAP but current generally accepted accounting practice is to recognise changes in value through reserves, such changes in value may be recognised through the statement of movements in equity until such time as there is an approved FRS that sets out the recognition requirements".
} 


\begin{tabular}{|l|c|}
\hline \multicolumn{2}{|l|}{ Table 5: Timeliness of actuarial valuation of accrued liabilities } \\
\hline Same or close to balance date & 16 \\
\hline One year previous & 44 \\
\hline Two years previous & 62 \\
\hline Three years previous & 37 \\
\hline Valuation not provided & 5 \\
\hline Total: & $\mathbf{1 6 4}$ \\
\hline
\end{tabular}

Two thirds of the reports had valuations at least two years old, and the analysis of the solvency or liquidity of the scheme is impaired when there has been a significant change in membership in that period. A few schemes that reported significant changes in membership had not undertaken a more recent valuation, as recommended by FRS 32 Para 5.24. The assessment of liabilities or solvency of such schemes is potentially compromised by this lack of timeliness. Information in most actuarial valuations provides value-relevant details of the financial condition of the scheme, and the recommendations for funding.

\section{Related party disclosures}

Related party disclosures were generally adequately reported, although it is not easy to determine property investments by a scheme where, for example, the scheme equity accounts for a $50 \%$ share of a property owning partnership (as in the BNZ scheme). Few schemes owned shares in their sponsor. Even sufficient related party disclosures cannot alleviate the current concern of the Government Actuary regarding scheme trustees' conflicts of interest; such as directors of the sponsoring entity signing using their company position where they should be signing as a trustee, or paying a benefit with regard to the company view rather than the interest of a beneficiary ${ }^{8}$. In my opinion, the value of having at least one independent trustee deserves more support from the industry. Such moves towards more independence in governance of schemes may also provide some protection of beneficiaries' interests if the sponsoring entity is in financial distress. Scheme assets need most protection from sponsoring entities during such periods. The plundering of pension funds just before the collapse of the Maxwell Group in the UK (Heath and Maxton 1997) drew attention to the lack of protection for private superannuation schemes in New Zealand.

\section{Other issues}

The examination of these 164 reports showed all but two of the schemes preferred the second format allowed by FRS 32: a statement of changes in net assets and a statement of net assets, a

\footnotetext{
${ }^{8}$ The Corporate Manager, 21/11/98, p. 38
} 
finding reflected also in the Laswad and Baskerville (1985) study. Early adoption by many schemes of the revised FRS 32 (1998) was also a feature.

\section{Summary of issues:}

The lapse of time between the most recent actuarial valuation and the financial report when there have been significant membership changes is a major concern. This is an issue particularly discussed in the discussion paper of FRED 20, the precursor to the UK FRS 17, and it was suggested that the increasing utilisation of sophisticated software facilitates timely reporting of accrued benefits. Thus requiring annual valuation of accrued benefits is viewed as increasingly cost/benefit efficient.

A minority of defined benefit superannuation schemes disregards some FRS 32 requirements.

Timeliness. More superannuation schemes could file in a timely manner; 41 reports filed at the Companies Offices did not have a balance date within the last fifteen months.

A significant gap in information presented was the number of members of the scheme. Although this is not specifically required by FRS 32, it is valuable information which should be included as part of the description of the scheme. This is because decisions concerning reversions or contribution holidays may be driven by different incentives when the beneficiaries are only a small number of higher-level management personnel. For example, the Air New Zealand Senior Executive Superannuation Scheme has \$2.6 million of assets and accrued benefit obligations with three members and no pensioners. In contrast, trading banks usually maintain very large defined benefit schemes for all full-time personnel. 


\section{Part 2: Funding levels of superannuation schemes in New Zealand}

There are two means of evaluating such data from defined benefit schemes:

a) Current funding level; in this study expressed as a \% of assets/accrued benefits. 26 schemes show funding levels under 100\%; for example the Wrightson Retirement Plan has assets of \$47 million and accrued benefits valued March '96 at \$67 million. This scheme would be funded to 74\%. At the other end of the scale, the Black \& Decker (NZ) Ltd Staff Superannuation Plan reported assets seven times the accrued benefits (713\%). The average level of funding for 160 schemes was $148 \%$. 4 schemes did not disclose accrued benefits.

b) Solvency of the scheme; in this study was expressed as a \% of assets/vested benefits. 8 schemes show solvency levels under 100\%; for example the Compair (NZ) Ltd Staff Super Plan has assets of $\$ .989$ million and vested benefits at $\$ 1.762$ million. This scheme would be (in)solvent at $56 \%$. At the other end of the scale, the Namco (New Zealand) Limited Superannuation Scheme reported assets twenty times the vested benefits (2008\%). The average level of solvency for 149 schemes was 199\%. 15 did not disclose vested benefits.

\begin{tabular}{|l|l|l|l|l|l|l|}
\hline \multicolumn{2}{|l}{ Table 6: Funding levels in New Zealand } & *CH & & Solvency & $* C H$ \\
\hline Funding & 10 & 3 & & Under $80 \%$ & 2 & \\
\hline Under $80 \%$ & 17 & 3 & & $80-100 \%$ & 4 & \\
\hline $80-100 \%$ & 36 & 16 & & $100-120 \%$ & 25 & 7 \\
\hline $100-120 \%$ & 27 & 9 & & $120-140 \%$ & 26 & 12 \\
\hline $120-140 \%$ & 35 & 18 & & $140-180 \%$ & 41 & 15 \\
\hline $140-180 \%$ & 30 & 20 & & Over $180 \%$ & 46 & 28 \\
\hline Over $180 \%$ & 4 & 3 & & n/a & 15 & 10 \\
\hline n/a & 1 & 1 & & & 1 & 1 \\
\hline$* *$ Excluded & $\mathbf{1 6 0}$ & $\mathbf{7 3}$ & & Total & $\mathbf{1 6 0}$ & $\mathbf{7 3}$ \\
\hline Total & & & & & & 26 \\
\hline
\end{tabular}

${ }^{*} \mathrm{CH}$ refers to how many in that bracket take a contribution holiday 
A recent Australian study (Ang, Gallery \& Sidhu, 1998) examines which information is more useful, and finds that accrued benefits have a lower explanatory power (value-relevance) than vested benefits. This result is contrary to some of the United States studies described further in this report, and merits further investigation. Examination of funding and solvency ratios shows that New Zealand defined benefit schemes are generally well-funded. Taken together, an examination of both vested benefit and accrued benefit measures provide a reasonable understanding of the scheme management.

\section{Is such information useful to shareholders of the sponsoring entity?}

In spite of concerns overseas with the size of liabilities for pension scheme obligations, this study to date has established that there are few schemes that would cause significant concern. On the other hand, there is no doubt that there are undisclosed assets for the entity sponsoring the scheme. When a scheme is well-funded there may be contribution holidays, reversions of assets to sponsors, and possibly the award of benefit improvements to employees by the employer. All three circumstances represent probable future economic benefits for the sponsoring entity. Therefore when a sponsoring entity operates a well-funded defined benefit scheme, there are likely to be undisclosed assets if there is neither note disclosure nor recognition in the financial statements of the surpluses in such schemes.

\section{Contribution holidays not taken as often as expected}

It is common for a sponsoring entity to take a "contribution holiday" (i.e. pay only a nominal $\$ 10$ or zero into the fund) when there is a material surplus. Of the 164 defined benefit schemes, 71 of the sponsoring entities take a contribution holiday. Interestingly, there are 28 schemes with a level of funding above $140 \%$ where the sponsor is not taking a contribution holiday ${ }^{9}$. This suggests some sponsoring entities are using superannuation schemes as a source of income smoothing through taking a contribution holiday to increase reported earnings for the sponsoring entity, or not taking a contribution holiday and reducing reported earnings.

\section{Reversions and terminations}

There have been strong arguments put forward that because the Trust deed of the scheme may prohibit the sponsoring entity from the right to superannuation scheme surpluses, therefore a surplus

\footnotetext{
${ }^{9}$ Asia Pacific Speciality Chemicals NZ Ltd Super Plan; Biro Bic (NZ) Limited Superannuation Scheme; Boehringer Ingelheim (N.Z). Limited Superannuation scheme; Brintons NZ Super Scheme; Coates New Zealand Superannuation Scheme; Compair (NZ) Staff Super Plan; Ecolab Ltd Superannuation Scheme; Foodstuffs (Wgtn) Co -op Staff Super Scheme; G L Bowron and Company Limited and Subsidiary Companies Retirement scheme; Garuda NZ Superannuation Fund; HarperCollins Publishers (New Zealand) Limited; Juken Nissho Limited staff superannuation scheme; McCann Erikson Ltd Staff Super Plan; Medical Assurance Staff Pension Fund; Milburn NZ Ltd Super Fund; Nalco Superannuation Scheme; Natural Gas Corporation Retirement Plan; NZ Bakels Superannuation Scheme; Penguin Books (NZ) Limited Superannuation Scheme; Pharmacia \& Upjohn New Zealand Superannuation Fund; Presbyterian Church NZ Beneficiary Fund; Rothmans of Pall Mall (New Zealand) Limited Pension Plan; Sandvik (NZ) ltd Superannuation scheme; Smith and Nephew Limited Staff Superannuation Scheme; United International Pictures Superannuation Fund; W R Grace (N.Z.) Limited Superannuation Fund; Weldwell (NZ) Limited Staff Superannuation Plan (1977); Wrigley Company (NZ) Limited Retirement Income Scheme.
} 
in the scheme should not be disclosed in the sponsoring entity's financial report. However, the discussion paper to FRED 20 suggested that a surplus should be recognised as an asset to the extent that the employer is able to recover the surplus either through reduced contributions in the future or through refunds (reversions) from the scheme ${ }^{10}$.

Case law in New Zealand has addressed the rights of the sponsor to have access to or protect their interest in surpluses in a scheme. Handling of these issues by the Courts has changed markedly since the UEB and Cullen cases in 1990-1992. There was considerable disagreement concerning the principles in these cases (Familton, 1993); since then the emphasis on contractual elements and scrutiny of the Trust deeds in their particular commercial setting has led to a more generous approach by the Courts towards reversion of surpluses to the sponsor and beneficiaries.

There is now a body of case law supporting a distribution of surpluses in schemes (including a reversion of assets) when all parties give their consent (e.g. Capral Fiduciary Ltd). Even when they don't, the courts have allowed such redistribution provided the interests of those dissenting are protected (see Table 7).

\begin{tabular}{|l|l|l|}
\hline Table 7: Three recent outcomes from case law \\
\hline $\begin{array}{l}\text { Holden New Zealand } \\
\text { Pension Plan } \\
\text { (High Court, Wgtn, } \\
\text { CP 121/98) }\end{array}$ & $\begin{array}{l}\text { All but four beneficiaries consented } \\
\text { to distribution of surplus, Trustees } \\
\text { proposed a sufficient sum would be } \\
\text { retained to secure their benefits. }\end{array}$ & $\begin{array}{l}\text { High Court was satisfied that the } \\
\text { amendments would not } \\
\text { adversely affect the four } \\
\text { beneficiaries'interests, and their } \\
\text { consent was not required. }\end{array}$ \\
\hline $\begin{array}{l}\text { Fletcher Challenge } \\
\text { Nominees Ltd v } \\
\text { Wrightson Ltd } \\
\text { (CA223/98) } \\
\text { (Ross, 1999) }\end{array}$ & $\begin{array}{l}\text { Wrightson Ltd separated from FC } \\
\text { Fletcher Plan to allocate assets on a } \\
\text { "share of the fund" basis rather than } \\
\text { a "benefits based" assessment. }\end{array}$ & $\begin{array}{l}\text { Court of Appeal allowed the } \\
\text { Trustees to take a benefit-based } \\
\text { in the Fletcher Plan in } \\
\text { Fletcher's interests). in }\end{array}$ \\
\hline $\begin{array}{l}\text { Capral Fiduciary Ltd } \\
\text { v Ladd (High Court } \\
\text { Auckland M 397/99) }\end{array}$ & $\begin{array}{l}\text { All members, pensioners and } \\
\text { sponsoring entity wanted to amend } \\
\text { the Trust Deed to allow a reversion. } \\
\text { Trust Deed had prohibited this. }\end{array}$ & $\begin{array}{l}\text { High Court held the Trust Deed } \\
\text { could be amended with the } \\
\text { consent of all parties. }\end{array}$ \\
\hline
\end{tabular}

What about the reports of the schemes themselves - what can this tell us? From the 164 reports, five reversions were noted:

\footnotetext{
${ }^{10}$ Recent activity concerning terminations of plans in the US are summarised in the article by Ellen E. Schultz "Pension Terminations become temptations for some employers. Wall Street Journal 15.6.99
} 


\begin{tabular}{|c|c|c|c|c|c|c|}
\hline \multicolumn{6}{|c|}{ Table 8: Reversion of Assets in Schemes } & \\
\hline Scheme & & Assets & Liabilities & Date & $\begin{array}{l}\text { Vested } \\
\text { benefits }\end{array}$ & \\
\hline $\begin{array}{l}\text { BOC Gases } \\
\text { New Zealand } \\
\text { Retirement Plan }\end{array}$ & $\begin{array}{l}31 / 3 / 9 \\
9\end{array}$ & $21,961,000$ & $\begin{array}{l}15,434,00 \\
0\end{array}$ & $1 / 4 / 96$ & $\begin{array}{l}14,738,00 \\
0\end{array}$ & $\begin{array}{l}\text { Reversion of } \$ 12.986 \text { mill. to sponsor and } \\
\text { pensioners in } 1999\end{array}$ \\
\hline $\begin{array}{l}\text { Capral } \\
\text { Retirement } \\
\text { Fund }\end{array}$ & $\begin{array}{l}31 / 3 / 9 \\
9\end{array}$ & $27,576,577$ & $\begin{array}{l}11,057,00 \\
0\end{array}$ & $\begin{array}{l}31 / 3 / 9 \\
6\end{array}$ & $8,912,788$ & $\begin{array}{l}\text { Temporarily closed to new members; } \\
\text { reversion proposal of } \$ 7.2 \text { mill. to Capral } \\
\text { under application; contribution holiday }\end{array}$ \\
\hline $\begin{array}{l}\text { Coopers and } \\
\text { Lybrand Staff } \\
\text { Superannuation } \\
\text { Plan }\end{array}$ & $\begin{array}{l}31 / 3 / 9 \\
9\end{array}$ & $5,471,471$ & $3,423,000$ & $1 / 4 / 96$ & $2,190,000$ & $\begin{array}{l}\text { There was a reversion of assets of } \$ 2.33 \\
\text { mill. in } 1999\end{array}$ \\
\hline $\begin{array}{l}\text { Guardian } \\
\text { Assurance } \\
\text { Superannuation } \\
\text { Plan }\end{array}$ & $\begin{array}{l}30 / 6 / 9 \\
9\end{array}$ & $41,027,258$ & $\begin{array}{l}31,743,00 \\
0\end{array}$ & $\begin{array}{l}30 / 6 / 9 \\
7\end{array}$ & $\begin{array}{l}27,198,00 \\
0\end{array}$ & $\begin{array}{l}\text { Reversion of surplus of } \$ 2.5 \text { mill in year } \\
\text { to June } 1999 \text { (also } \$ 2.5 \text { mill in 1998); }\end{array}$ \\
\hline $\begin{array}{l}\text { Holden NZ } \\
\text { Limited Pension } \\
\text { Plan }\end{array}$ & $\begin{array}{l}30 / 6 / 9 \\
9\end{array}$ & $11,410,740$ & $\begin{array}{l}10,330,00 \\
0\end{array}$ & $\begin{array}{l}30 / 6 / 9 \\
9\end{array}$ & $1,006,000$ & \$31.8 mill. reversion in 1998 \\
\hline
\end{tabular}

These reversion dates do not tie closely to the total of reversions to sponsoring entities approved by the Government Actuary, as reported annually to Parliament. The total of $\$ 56.8$ million from these five superannuation scheme reports is materially higher than the total of $\$ 32$ million disclosed by the Government Actuary in the last three years ('97 - '99). It is also very likely there are additional reversions in schemes now closed to new members that do not have to file at the Companies Offices. The difference may be because the total amount in the financial report of the schemes includes distributions to members. In summary, the probability of Courts allowing a reversion of assets to the sponsoring entity, even when the Trust deed does not permit such an action, means that material surpluses in superannuation schemes represent probable future economic benefits to the sponsoring entity.

There is a history of contentious cases concerning the employers' rights to reversions, starting from the UEB case, when New Zealand Equities Ltd gained control of UEB in 1986. They opted to wind up the DBS of UEB worth \$73 million. In March 1987 there were 1650 members and 342 pensioners. After 1/12/98 there were 250 members. The 1988 financial results for New Zealand Equities Ltd showed a \$21 million surplus from the fund as part of its assets. 1300 members of the scheme challenged their right to these funds. NZE argued UEB had contributed twice as much as the employees; members of the scheme claimed the payment of \$21 million was beyond the powers of the trustees; and the trust deed did not extend to authorising the payment; if 
the trust deed was constructed to authorise it, changes to the deed were invalid. The Court decided members of the scheme had been adversely affected by the changes; this was confirmed by the Court of Appeal in 1991, and did not go to the Privy Council.

In 1991 the case of Cullen v Pension Holdings concerned the New Zealand Farmers Coop superannuation scheme. The Coop and Whitcoulls were both subsidiaries of Brierleys; Whitcoulls staff were intended to be allowed to join the Co-op superannuation scheme, which had a surplus. However, the Courts reversed this decision and decided in favour of the beneficiaries of NZFC.

There were two cases concerning the BNZ Officers' Provident Association (established in 1900). In the first case, the trustees were required to allocate benefits to members according to scheme rules, in spite of a large and growing actuarial surplus. The trustees could not take the global earnings figures and divide that by total member contributions to allocate funds to the DBS and the DCS. The second case which came to the High Court in 1998 was because the members claimed that the Bank should stop the contribution holiday it enjoyed, freeze the surplus, and repay the $\$ 141$ million its contribution holiday had used up. Members claimed the fund had not been run properly since the rules were changed to allow the employer to fund its contributions from the surplus ${ }^{11}$. Judge Ellis ruled that indeed the BNZ could enjoy the benefits of the surplus through a contribution holiday ${ }^{12}$.

There are other cases involving the sponsoring entity's rights to scheme surpluses. In the light of the international consensus by standard-setters, and from US research, there is little basis for the conservative view still advocated in New Zealand that the assets of the scheme embodied in a scheme surplus are not assets of the sponsoring entity. The increasing availability of information concerning surpluses in the public domain could be expected to lead to more systematic note disclosures by listed companies in the near future.

Having examined the funding of 164 schemes, it is appropriate in the next section to examine in detail show well investors in New Zealand are currently being provided with information concerning superannuation schemes related to listed companies.

\footnotetext{
${ }^{11}$ Independent, 1.7.98, Page 25

${ }^{12}$ Commercial Business Feb. 15, 1999 Page 2
} 


\section{Part 3: Listed company disclosures in New Zealand.}

There are 21 listed companies in New Zealand which are sponsoring 29 superannuation schemes, some of which are closed to new members or being wound up:

\section{Table 9: Listed companies disclosures in New Zealand}

\begin{tabular}{|c|c|c|c|c|c|c|c|c|}
\hline & & $\begin{array}{l}\text { Scheme } \\
\text { report } \\
\text { at Co's } \\
\text { Office }\end{array}$ & $\mathbf{A} / \mathbf{L}$ & $\begin{array}{l}\text { Assets } \\
\text { (\$mill.) }\end{array}$ & $\begin{array}{l}\text { Surplus } \\
\text { (\$mill.) }\end{array}$ & $\begin{array}{l}\text { Time- } \\
\text { liness }\end{array}$ & Comments & Pension schemes \\
\hline $\begin{array}{l}\text { Affco Holdings } \\
\text { Ltd }\end{array}$ & $\begin{array}{l}\text { no } \\
\text { disclosures } \\
\text { in } 1998 \text { co. } \\
\text { a/cs }\end{array}$ & Mar-99 & $108 \%$ & 18.65 & 1.44 & $\mathrm{~B}$ & $\begin{array}{l}\text { Plan is in "a good financial } \\
\text { position" }\end{array}$ & $\begin{array}{l}\text { Affco Staff } \\
\text { Superannuation Plan }\end{array}$ \\
\hline Air NZ Ltd & $\begin{array}{l}\text { no } \\
\text { disclosures } \\
\text { in } 1998 \mathrm{co} \text {. } \\
\text { a/cs }\end{array}$ & Mar-98 & $106 \%$ & 2.64 & 0.16 & $\mathrm{~B}$ & $\begin{array}{l}3 \text { members; no pensioners; } \\
\text { sponsor to pay } 10.3 \% \text { of salaries; } \\
\text { no cash inflow from contributions } \\
\text { in } 1998\end{array}$ & $\begin{array}{l}\text { Air New Zealand Limited } \\
\text { Senior Executive } \\
\text { Superannuation Scheme }\end{array}$ \\
\hline \multirow[t]{2}{*}{ AMP Ltd } & $\begin{array}{l}1999 \\
\text { Note } 33\end{array}$ & Dec-98 & $175 \%$ & 89.16 & 38.35 & $\mathrm{~B}$ & $\begin{array}{l}\text { sound financial position; sponsor } \\
\text { to contribute } \$ 10 \text { p.a. from } 1.1 .98\end{array}$ & $\begin{array}{l}\text { AMP New Zealand Staff } \\
\text { Superannuation Plan }\end{array}$ \\
\hline & & & & & & & Closed to new members; not filed & $\begin{array}{l}\text { AMP (New Zealand) Staff } \\
\text { Superannuation Plan - L/S }\end{array}$ \\
\hline \multirow[t]{2}{*}{$\begin{array}{l}\text { Brierley } \\
\text { Investments Ltd }\end{array}$} & $\begin{array}{l}\text { no } \\
\text { disclosures } \\
\text { in } 1999 \text { co. } \\
\text { a/cs }\end{array}$ & Mar-99 & $7 \%$ & 0.02 & -0.30 & $\mathrm{C}$ & $\begin{array}{l}\text { BIL underwrites the fund "when } \\
\text { and to the extent necessary" }\end{array}$ & $\begin{array}{l}\text { Brierley Investments } \\
\text { Limited Superannuation } \\
\text { Fund }\end{array}$ \\
\hline & & & & & & & Closed to new members; not filed & $\begin{array}{l}\text { Union Shipping Group } \\
\text { Retirement Plan }\end{array}$ \\
\hline $\begin{array}{l}\text { Carter Holt } \\
\text { Harvey Ltd }\end{array}$ & $\begin{array}{l}\text { no } \\
\text { disclosures } \\
\text { in } 1999 \text { co. } \\
\text { a/cs }\end{array}$ & Jun-99 & $119 \%$ & 104.81 & 16.69 & $\mathrm{C}$ & $\begin{array}{l}\text { Contribution holiday for sponsor; } \\
\text { scheme holds shares of valued at } \\
\$ 103,353 \text { in CHH Ltd; plan in " a } \\
\text { strong financial position". }\end{array}$ & $\begin{array}{l}\text { Carter Holt Harvey } \\
\text { Retirement Plan }\end{array}$ \\
\hline $\begin{array}{l}\text { Ceramco } \\
\text { Corporation Ltd }\end{array}$ & $\begin{array}{l}1998 \text { Note } 8 \\
\& \text { surplus } \\
\text { from } \\
\text { pension } \\
\text { plan in } \\
\text { S.Fin.Perf }\end{array}$ & Mar-99 & $13 \%$ & 0.03 & -0.23 & $\mathrm{~B}$ & $\begin{array}{l}\text { At time of last actuarial valuation } \\
\text { scheme was in deficit by } \$ 219,000\end{array}$ & $\begin{array}{l}\text { Ceramco Superannuation } \\
\text { Plan }\end{array}$ \\
\hline \multirow[t]{2}{*}{ DB Group Ltd } & $\begin{array}{l}\text { no } \\
\text { disclosures } \\
\text { in } 1999 \text { co. } \\
\text { a/cs }\end{array}$ & Mar-99 & $154 \%$ & 31.15 & 10.98 & $\mathrm{~B}$ & $\begin{array}{l}\text { Sound financial condition; } \\
\text { contribution holiday except for } \\
\text { one subsidiary company }\end{array}$ & $\begin{array}{l}\text { DB Group Employee } \\
\text { Benefits Scheme }\end{array}$ \\
\hline & & Mar-99 & $96 \%$ & 0.39 & -0.02 & $\mathrm{D}$ & $\begin{array}{l}\text { Satisfactory financial position; } \\
\text { contribution holiday; } 5 \text { pensioners; } \\
\text { no active members }\end{array}$ & $\begin{array}{l}\text { Dominion Breweries } \\
\text { (1986) Employee Benefits } \\
\text { Scheme }\end{array}$ \\
\hline $\begin{array}{l}\text { Fisher \& Paykel } \\
\text { Industries } \\
\text { Limited }\end{array}$ & $\begin{array}{l}\text { disc } \\
\text { disclosures } \\
\text { in } 1998 \text { co. } \\
\text { a/cs }\end{array}$ & Mar-98 & $119 \%$ & 99.49 & 15.90 & $\mathrm{~B}$ & $\begin{array}{l}\text { Related Party Disclosures: holds } \\
\text { shares in sponsor to value of } \\
\$ 288,365 \text {. }\end{array}$ & $\begin{array}{l}\text { Fisher \& Paykel Industries } \\
\text { Limited Staff } \\
\text { Superannuation Plan }\end{array}$ \\
\hline $\begin{array}{l}\text { Goodman } \\
\text { Fielder Ltd }\end{array}$ & $\begin{array}{l}\text { 1998: Note } \\
32 \text { \& Note } 1\end{array}$ & Sep-98 & $123 \%$ & 5.64 & 1.04 & $\mathrm{~B}$ & & $\begin{array}{l}\text { Ernest Adams Ltd Pension } \\
\text { Plan (1979) }\end{array}$ \\
\hline
\end{tabular}

\footnotetext{
${ }^{13}$ Timeliness of valuation of accrued liability: $\mathrm{A}=$ up to 6 months before balance date; $\mathrm{B}=$ up to 1.5 years; $\mathrm{C}=$ up to 2.5 years; $\mathrm{D}=$ over 2.5 years
} 


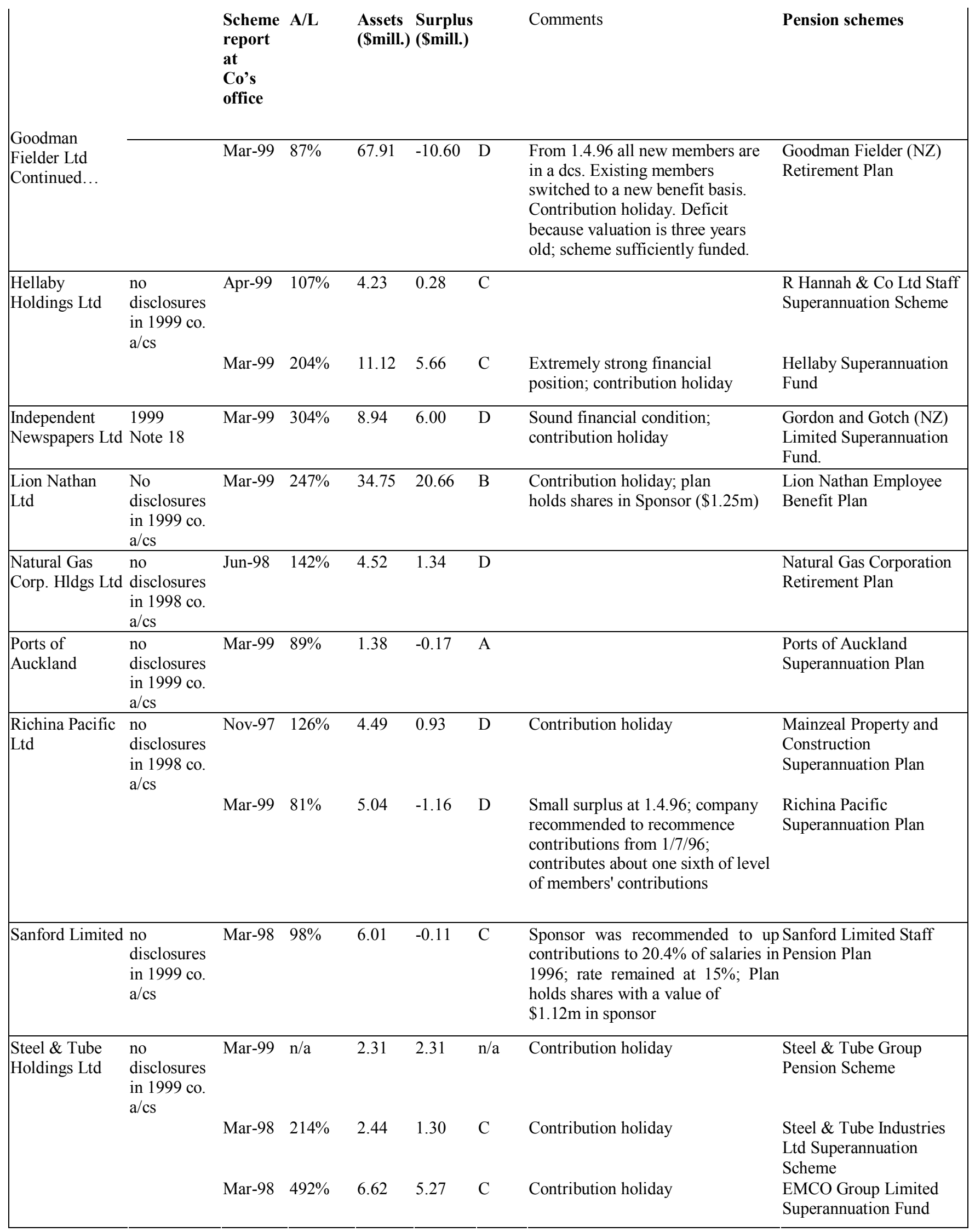




\begin{tabular}{|c|c|c|c|c|c|c|c|}
\hline $\begin{array}{l}\text { Westpac Ltd } \\
1999\end{array}$ & $\begin{array}{l}1999 \\
\text { Note } 29\end{array}$ & Jun-98 & $172 \%$ & 300.14 & 125.89 & $\mathrm{C}$ & $\begin{array}{l}\text { Contribution holiday; scheme holds Westpactrust New } \\
\text { shares in sponsor valued at \$Aus Zealand Staff } \\
20,094 \quad \text { Superannuation Scheme }\end{array}$ \\
\hline $\begin{array}{l}\text { Williams and } \\
\text { Kettle Ltd }\end{array}$ & $\begin{array}{l}1999 \\
\text { Note } 24\end{array}$ & Mar-99 & $153 \%$ & 26.18 & 9.09 & $\mathrm{D}$ & $\begin{array}{l}\text { Contribution holiday for sponsor; Williams and Kettle } \\
\text { scheme holds shares valued at Limited Staff Pension } \\
\$ 288,000 \text { in sponsor }\end{array}$ \\
\hline Wrightson Ltd & $\begin{array}{l}\text { no } \\
\text { disclosures } \\
\text { in } 1999 \text { co. } \\
\text { a/cs }\end{array}$ & Jun-98 & $74 \%$ & 49.78 & -17.33 & $\mathrm{C}$ & $\begin{array}{l}\text { Wrightson Retirement } \\
\text { Plan }\end{array}$ \\
\hline
\end{tabular}


For comparison, some other schemes not related to listed companies which show large surpluses are:

Table 10: Well-funded schemes other than those associated with NZ listed companies

\begin{tabular}{|c|c|c|c|}
\hline & $\begin{array}{l}\text { Total } \\
\text { Superannuat } \\
\text { ion assets }\end{array}$ & Surplus & Notes: \\
\hline $\begin{array}{l}\text { Bank of New Zealand Officers } \\
\text { Provident Association }\end{array}$ & $305,708,000$ & $106,600,000$ & $\begin{array}{l}50 \% \text { interest in BDS Partnership - owns property; } \\
\text { equity accounted; sponsor has contribution } \\
\text { holiday; also members are permitted to accrue } \\
\text { additional service }\end{array}$ \\
\hline $\begin{array}{l}\text { Shell New Zealand Pension } \\
\text { Plan }\end{array}$ & $209,471,000$ & $58,003,000$ & $\begin{array}{l}\text { "financial position is sound"; plan’s shares in Shell } \\
\text { Group }(\$ 954,000) \text { were sold May '99 }\end{array}$ \\
\hline $\begin{array}{l}\text { National Mutual New Zealand } \\
\text { Superannuation Scheme }\end{array}$ & $99,751,487$ & $34,751,487$ & Contribution holiday \\
\hline $\begin{array}{l}\text { Canterbury Frozen Meat } \\
\text { Company Ltd Staff } \\
\text { Superannuation Plan }\end{array}$ & $66,174,535$ & $26,200,000$ & $\begin{array}{l}\text { Contribution holiday; combined des and dbs; } \\
\text { "strong financial position" }\end{array}$ \\
\hline $\begin{array}{l}\text { Heinz-Wattie Limited Pension } \\
\text { Plan }\end{array}$ & $54,918,764$ & $16,576,764$ & $\begin{array}{l}\text { "sound financial; position"; contribution holiday; } \\
\text { RPD: rental income from Tegel Foods Limited for } \\
\text { a chicken breeding farm. } 160 \text { Tip Top employees } \\
\text { left the Plan 30/4/98 }\end{array}$ \\
\hline Capral Retirement Fund & $27,576,577$ & $16,519,577$ & $\begin{array}{l}\text { Temporarily closed to new members: "extremely } \\
\text { sound financial position"; reversion proposal of } \\
\$ 7.2 \text { mill. To Capral under application; } \\
\text { contribution holiday }\end{array}$ \\
\hline $\begin{array}{l}\text { The Church of Jesus Christ of } \\
\text { the Latter Day Saints }\end{array}$ & $22,210,000$ & $12,163,000$ & Contribution holiday: a combined dbs and des \\
\hline $\begin{array}{l}\text { Rothmans of Pall Mall (New } \\
\text { Zealand) Limited Pension Plan }\end{array}$ & $23,855,244$ & $11,845,244$ & $\begin{array}{l}\text { "strong financial position"; at last actuarial review } \\
\text { contribution holiday recommended to sponsor, but } \\
\text { not taken (sponsor contributes approx. one quarter } \\
\text { the level of members' contributions) }\end{array}$ \\
\hline $\begin{array}{l}\text { Guardian Assurance } \\
\text { Superannuation Plan }\end{array}$ & $41,027,258$ & $9,284,258$ & $\begin{array}{l}\text { Reversion of surplus of } \$ 2.5 \text { mill in yr to June } \\
1999 \text { (also } \$ 2.5 \text { mill in } 1998 \text { ); "financial position } \\
\text { of the plan remains very strong"; contribution } \\
\text { holiday }\end{array}$ \\
\hline $\begin{array}{l}\text { British American Tobacco New } \\
\text { Zealand Superannuation Fund }\end{array}$ & $23,978,371$ & $9,118,371$ & $\begin{array}{l}\text { "the Fund's assets comfortably exceed the value of } \\
\text { past service benefits". Contribution holiday }\end{array}$ \\
\hline $\begin{array}{l}\text { Caltex New Zealand Limited } \\
\text { Staff Pension Plan }\end{array}$ & $39,835,842$ & $8,969,842$ & Vested benefits are decreasing \\
\hline $\begin{array}{l}\text { Royal \& Sun Alliance New } \\
\text { Zealand Pension Scheme }\end{array}$ & $46,716,482$ & $8,684,482$ & $\begin{array}{l}\text { "sound financial condition"; non-contributory for } \\
\text { members (see also Commercial Union Staff } \\
\text { Pension Scheme). }\end{array}$ \\
\hline
\end{tabular}


Such indications of surpluses in superannuation schemes might be expected to be reflected in some Note disclosures by companies. As far as listed companies are concerned, an examination was made of 133 company reports on the 1999 Datex Annual Report Database.

\begin{tabular}{|c|c|}
\hline AMP Ltd & $\begin{array}{l}\text { Note } 25 \text { referred to a provision of } \$ 1,145 \text { million included in Provisions on balance } \\
\text { Sheet for "pensions, transfers and opt-outs". } \\
\text { Note } 33 \text { provided a full-page description of } \$ 234 \text { million of employee entitlements } \\
\text { (and included a description of five major defined benefit plans). Due to surpluses, } \\
\text { AMP had not contributed to four of these five plans. }\end{array}$ \\
\hline Apple Fields Ltd & $\begin{array}{l}\text { Detail in Notes to the Accounts (Note 28) of guarantees fur Rural Super Bonds } \\
\text { Superannuation Scheme, and the legal rights to RSB for set off with AFL. }\end{array}$ \\
\hline J Boag \& Son Ltd & $\begin{array}{l}\text { Detail in: } \\
\text { Statement of Accounting Policies } \\
\text { Note } 3 \text { - Operating Expenses include } \$ 566,000 \text { contribution to schemes. } \\
\text { Note } 17 \text { - } 2 \text { paragraph description of two major superannuation funds. }\end{array}$ \\
\hline Ceramco Corp Ltd & $\begin{array}{l}\text { Note } 8 \text { included pension liabilities of } \$ 1.198 \text { million in non-current liabilities. The } \\
\text { surplus from commutation of pensions of } \$ 1.4 \text { million was credited as part of non- } \\
\text { recurring items in the Income Statement. }\end{array}$ \\
\hline Colonial Ltd & $\begin{array}{l}\text { Note } 34 \text { provided a full description of eleven defined benefit schemes, only one of } \\
\text { which showed net assets lower than accrued benefits. In addition, the names of } \\
\text { twelve accumulation funds (DCSs) were listed, but with no detail. }\end{array}$ \\
\hline FC Ltd & $\begin{array}{l}\text { Complied fully with SFAS } 87 \text { requirements, recognizing } \$ 30 \text { million of scheme } \\
\text { assets in balance sheet. }\end{array}$ \\
\hline Goodman Fielder Ltd & $\begin{array}{l}\text { Note } 32 \text { - a two-page description of } 10 \text { DBSs, for which two granted a contribution } \\
\text { holiday in 1998. The total excess of assets over present net accrued benefits was } \\
\$ 68.5 \text { million. It appears that since } 1997 \text { all staff belonging to one of these schemes } \\
\text { have defined contribution benefits, with earlier members retaining a defined benefit } \\
\text { guarantee. } \\
\text { The names of the four DCSs are also listed. } \\
\text { Note } 1 \text { noted that any deficiency in net assets is recognized as a liability if material. }\end{array}$ \\
\hline $\begin{array}{l}\text { McConnell Dowell Corp } \\
\text { Ltd }\end{array}$ & $\begin{array}{l}\text { Note } 16 \text { (Contingent Liabilities) provided brief detail of } 2 \text { accumulation funds } \\
\text { (DCSs), in which funds were sufficient to meet obligations. }\end{array}$ \\
\hline $\begin{array}{l}\text { National Mutual } \\
\text { Holdings Ltd }\end{array}$ & $\begin{array}{l}\text { Statement of Accounting Policies noted contributions are expensed as incurred and } \\
\text { consolidation inappropriate due to lack of direct or indirect control by the Company. } \\
\text { Note } 25 \text { described three defined benefit schemes with assets in excess of } \$ 20 \\
\text { million. Surplus of assets over accrued benefits for these three schemes totaled } \$ 134 \\
\text { million. }\end{array}$ \\
\hline Telstra Corp Ltd & $\begin{array}{l}\text { Inclusion of amounts owing to superannuation scheme in "accounts payable". Two } \\
\text { paragraphs in Statement of Accounting Policies broadly describing superannuation } \\
\text { schemes. No detail of type or size. }\end{array}$ \\
\hline $\begin{array}{l}\text { Tranz Rail and Telecom } \\
\text { NZ Ltd (ex State Owned } \\
\text { Enterprises) }\end{array}$ & $\begin{array}{l}\text { Both entities provided a brief paragraph in the Statement of Accounting Policies } \\
\text { described existing commitments for contributions to the Government } \\
\text { Superannuation Fund. }\end{array}$ \\
\hline Williams \& Kettle Ltd & $\begin{array}{l}\text { Note } 24 \text { - one paragraph reference to a Staff Pension Fund, noting only that the fund } \\
\text { had no borrowings. }\end{array}$ \\
\hline $\begin{array}{l}\text { Infratil Aust. Ltd and } \\
\text { Progressive Enterprises } \\
\text { Ltd }\end{array}$ & $\begin{array}{l}\text { One line disclosure: in Statement of Accounting Policies: that contribution to } \\
\text { superannuation plans are expensed as incurred. }\end{array}$ \\
\hline $\begin{array}{l}\text { Infratil Aust. Ltd and } \\
\text { Progressive Enterprises }\end{array}$ & $\begin{array}{l}\text { disclosure: in Statement of Accounting Policies: } \\
\text { ibutions to superannuation plans are expensed as }\end{array}$ \\
\hline
\end{tabular}


This section of the working paper concerning funding levels and disclosures by New Zealand companies has shown that many schemes are well funded, and companies appear to be exercising some discretion concerning whether or not to avail themselves of a contribution holiday, and whether or not to provide any disclosure of such details by way of Note. Shareholders in sponsoring companies would find inconsistencies in the quality of disclosures, making an understanding of possible assets or liabilities for the sponsoring entity difficult.

\section{Research concerning the market perception of the relevance of superannuation disclosures}

In the mid-20th century trust law very much favoured the perception of superannuation schemes as being entities distinct from the sponsoring entity. As described already in the case law on reversions of assets, there has been a noticeable shift to consider superannuation schemes as substantially similar to subsidiaries of reporting entitles. This is further confirmed by research in the Untied States. The following review of research on this has been divided into studies looking at:

- Disclosure Issues

- The FAS 36 database, and issues in the development of SFAS 87

- Termination studies

- Reversions

- Application of SFAS 87 Employers' Accounting for Pensions (1985)

\section{Disclosure Issues}

Much of the earlier research prior to the promulgation of SFAS 87 Employers' Accounting for Pensions (1985) in the USA focused on disclosure issues, and this will probably be the literature into which New Zealand research will be embedded. Previous studies in the United States included a 1991 report by Harper, Mister and Strawser. A sample of commercial lenders was surveyed to determine whether the method of reporting the obligation for unfunded postretirement benefits affected user perceptions of this item as a form of debt. Survey results revealed that commercial lenders were more likely to perceive this obligation 
as a form of debt when recognized as a balance sheet liability than when disclosed in the footnotes accompanying the financial statements.

In 1993 Gopalakrishnan and Sugrue undertook an empirical investigation of stock market valuation of corporate projected pension liabilities. The analysis offered a technical perspective by decomposing the projected benefit obligations into three components vested benefits, accumulated benefits, and future salary progression; and examining the stock market perception of these components of pension obligations. The findings indicated that investors perceive pension assets and pension liabilities as, respectively, corporate assets and liabilities. The results also validated prior findings that pension fund property rights lie fully with the firm as opposed to the pension trust.

In 1994 Scott tested the voluntary disclosures of Canadian firms pension plans against Verrecchia's 1983 proprietary cost theory compared with Diamond's 1985 information cost savings hypothesis. The former appears supported, whereas evidence for the latter is equivocal. Proprietary costs mitigate the adverse selection argument in favour of full disclosures; moreover, the disclosures are conditioned on the favourableness of the news. Proxies representing proprietary costs related to labour are negatively associated with firms' defined benefit schemes disclosures.

A sole Australian study by Ang, Gallery and Sidhu (1999) investigated the value relevance of (employer sponsored defined benefit plan) superannuation disclosures required by AASB 1028. It addressed the competing claims by standard setters and lobbyists that such disclosures would (not) enhance the relevance and reliability of financial statements. It presents three principal findings. First, disclosed superannuation information is value relevant in the industrial sector, where these items tend to be material. Second, the market weights on the required disclosures are typically higher than those on recognised assets and liabilities. Third, and in contrast to the findings in similar US studies, accrued benefits do not have higher explanatory power relative to vested benefits.

\section{The FAS 36 database, and issues in the development of SFAS 87}

Up to the issue of SFAS 87 there were some of studies that drew on the FAS 36 database. This was a collection of data concerning defined benefit pension plans that was taken into account during the development of SFAS 87. For example Daly (1984) used a cross sectional 
equity valuation model to assess the consistency of the three alternative accounting measures for pension costs estimates. Landsman (1986) examined the relationship between pension fund assets and liabilities associated with corporate-sponsored defined benefit pension plans and the market value of shareholder equity, using an equity valuation based on balance sheet identity. This model permitted pension and non-pension assets and liabilities to have separate empirical coefficient values. Selling and Stickney (1986) examined the associations between three alternative measures of the unfunded pension obligation and a measure that reflects the present value of expected cash flows (economic liability). The sensitivity of the correlations to funding techniques, growth rates of the plan population, interest rates, plan initiation dates, and extent of sweetening also were investigated. The results 17 indicated that all the accounting measures of the pension obligation were highly correlated with the total economic liability when funding is excluded, but that the correlations decrease considerably when the net (unfunded) liability is examined. It was further demonstrated that one cannot predict ex ante which measure of the unfunded liability will be most highly correlated with the economic liability. The implication for accounting standard-setting bodies is that both pension plan assets and pension obligations should be disclosed to help users make predictions about changes in the economic liability.

Harper, Mister, Strawser, and Summers (1990) conducted a study to determine if internal auditors' perceptions of a firm's unfunded pension obligations are affected by a change in the format of pension disclosures as required by SFAS 87. The results indicated that the form of the disclosure can affect the perceptions of the underlying economic substance. Barth (1991) found that: a) footnote disclosures are closer to those assessed market valuations than are the measures recognized in the balance sheet, and b) investors appear to include expectations about future salary progression in assessing pension liabilities but view the projected benefit obligation measure as noisy.

In the same year Lander, Reinstein, and Fosu evaluated agency theory influence in pension accounting. Discussions in SFAS 87 had ignored the central economic consideration that any plan must benefit the employer. An analysis using a decision model showed that once a pension plan is adopted, services to date are the labour service that the employee provided. SFAS 87 also requires that the pension liability should reflect pension plan amendments. However, if the employer's objective is to maximize utility, then the increased benefits would result from a revision of the estimated future cost savings or a revision of the cost savings 
sharing rate. To be consistent, the benefit obligation resulting from plan amendments and expressed as a function of prior years of service should be recognized as a deferred liability, amortized as future cost savings services are provided.

\section{Termination studies}

There have been a number of studies addressing issues surrounding termination of pension funds. Hamdallah and Ruland (1986) conducted a survey to determine which factors are associated with the termination of pension plans. The sample consisted of 40 publicly held firms that terminated their overfunded pension plans and 40 firms that did not terminate their overfunded pension plans. According to the results of the statistical analysis, the management and business variables exhibited by companies that terminated funds include: 1. a lack of union employees, 2. small size, 3. tax carry forwards, 4. high financial leverage, 5. management compensation plans based on income, and 6. high owner control. The findings indicate the influence of managers' personal interests on termination decisions.

Stone (1987) looked at the question: can overfunded pension plan termination be explained as a financing decision. An analysis of 208 firms, in which 58 terminated plans during the period of study, indicated that firms terminating overfunded plans can be identified on the basis of their need for financing, the market valuation of their cash flow and the disincentives to additional debt financing.

Mittelstaedt (1989) examined three related hypotheses for explaining reductions of excess assets in legally overfunded pension plans. Proxies for shifts in financial weakness, susceptibility to takeover, and marginal tax rate are explored. Firms in the sample are classified as:

- terminators (firms terminating plans),

- contractors (firms reducing annual contributions by more than $40 \%$ through changes in actuarial assumptions, and

- maintainers (firms reducing annual plan contributions by less than $30 \%$ ).

Multivariate and univariate tests are conducted to distinguish the three hypotheses. The results showed that the financial weakening hypothesis appears to be the most plausible in explaining pension plan reductions. Firms are more likely to be terminators when cash 
requirements are high and firms are experiencing severe financial weakening. Firms are more likely to be contractors when cash needs and financial weakening are lower.

These results were similar to those of Thomas (1989) who identified that firms that terminate their overfunded pension plans generally fall into one of three categories. These firms are involved in terminations that:

- are not associated with control changes,

- are followed by hostile attempts to change control, or

- follow friendly control changes.

Terminations for firms in the third group are apparently motivated by plan consolidation considerations, unlike the terminations in the first two groups. Analyses of terminations falling in the first two groups did not provide any evidence that the terminations represent a breach of explicit contracts. The results of the analyses also suggest that financial statement-based incentives are not likely to be the primary factor motivating pension plan terminations (a surprising finding?). For terminations not associated with corporate control changes, large and persistent declines in cash flows from operations are observed before the year of termination. Tight financial conditions engendered by the restructuring that typically follows hostile takeover attempts also appear to be associated with terminations. Further evidence on excess asset reversions and shareholder wealth from Mittelstaedt and Reiger (1990) re-evaluated prior research and extended it in two ways: 1. The study included firms terminating plans after mid- 1984, when federal guidelines on reversions were finalized. 2. It used a sample selection procedure allowing event dates to be determined from initial announcements in the Dow Jones News Service or the Wall Street Journal, rather than relying exclusively on the Pension Benefit Guaranty Corp. notification dates. It is found that the significantly positive results disappear when:

- more precise event dates are used,

- terminations with confounding events are eliminated, and

- samples are comprised mainly of terminations occurring after the issuance of joint federal agency guidelines. 
Their 1993 study of market response to pension plan terminations analysed stock returns associated with the announcement to terminate overfunded defined-benefit pension plans. The results suggested that the form of the replacement plan and, to a lesser degree, market anticipation, affects stock returns at the time of termination. The results are consistent with investors' use of future salaries to value pension liabilities prior to termination.

\section{Reversions}

Other studies focussed on the broader issue of reversions. In 1989 Pontiff, Shleifer and Weisbach (1989) took a sample of 413 takeovers between 1981 and 1988: pension funds were reverted by $15.1 \%$ of acquirers in the 2 years following hostile takeovers, compared with $8.4 \%$ in the 2 years following friendly takeovers. Reversions following takeovers tend to occur in unit-benefit plans, where the potential for wealth transfer is the greatest. These results are consistent with the view that hostile takeovers breach implicit contracts between firms and employees. It is estimated that the reversions, on average, can explain about $11 \%$ of the takeover premium in cases where they actually occur. Reversions are too small to be the sole, or even dominant, source of takeover gains. One other study in 1996 by Clinch and Shibano determined that tax considerations influence whether and when a firm withdraws excess assets in its defined benefit pension plan through a reversion. Since a reversion impacts taxable income over many years and alternative methods of withdrawing excess assets exist, it was argued that the economy relevant tax-based decision criterion is its differential tax benefit, defined as the difference between the discounted tax savings of reversion versus those of the best alternative withdrawal method. A technique was used for directly estimating this decision criterion, and documented that differential tax benefits are strongly correlated with the reversion decision and its timing.

\section{SFAS 87 Employers' Accounting for Pensions}

When SFAS 87 Employers' Accounting for Pensions (1985) was issued, Scott (1991) analysed how 279 firms responded to the opportunity to adopt the new pension accounting standard 1986 rather than 1987. The influence of political and agency variables and three income-related variables were tested with regard to this accounting choice. The political variables, management compensation contracts, the magnitude of the income effect of adoption, whether the firm was a "bath" firm, and the earnings position of the firm relative to the prior year were all associated with the adoption choice. 
Sami and Welsh (1992) also examined issues associated with the adoption of SFAS 87 by testing whether systematic differences exist between firms that chose early rather than late adoption of SFAS 87. A sample of 67 US firms adopting SFAS 87 earlier than required was identified, along with a matching sample of firms that did not adopt SFAS 87 early. The results indicated that early adopters were large firms with more fully funded pension obligations. They were subject to more accounting-based debt constraints, especially on working capital, and were more constrained on interest coverage than were firms that did not adopt SFAS 8719 early. The results also supported the hypothesis that firms adopting SFAS 87 early have a smaller percentage of stock owned by management.

Carpenter and Mahoney (1992) suggested three serious shortcomings in SFAS 87 were:

- the recognition of certain liabilities and expenses are deferred to future periods, which may cause financial statement users to overestimate the financial integrity of both the pension plan and the sponsoring company,

- certain obligations may be offset by items reported as assets that fail to meet most financial statement users' commonly held definitions of assets; and

- there appears to have been a tendency for the FASB to have opted for the less conservative criteria when given choices in the development of FASB 87.

Gopalakrishnan and Sugrue (1992) extended the economic consequences literature by directly examining the private and public lending agreements for a sample of 26 firms that were affected by the recognition of the unfunded accumulated liability on the balance sheet under SFAS 87. The results of the multivariate regression analysis indicated that compliance with SFAS 87 would have resulted in technical violations or substantial reduction in debt covenant slack for more than $65 \%$ of the sample. However, no significant security price change is observed during the Financial Accounting Standards Board's pension policy deliberations period. SFAS 87 appears to have had little economic consequences through its impact on slack present in accounting based debt covenants. The results offered no support for the debt-covenant hypothesis discussed in the extant literature.

In 1993 Ali and Kumar presented evidence indicating a greater influence of accounting incentives on reported pension cost under the current pension accounting standard SFAS 
87 relative to the preceding standard, Accounting Principles Board Opinion No. 8 (APB 8). Using the difference between the income reported under SFAS 87 and APB 8 in the adoption year as a measure that incorporates the difference between the discretionary components of pension cost under the two regimes, they showed that this difference is associated with proxies for managers' accounting incentives. Even though SFAS 87 appeared to have been successful in moving pension accounting away from cash basis and toward accrual basis, the increased influence of accounting incentives may have hampered the comparability across firms of the reported pension numbers and hence their usefulness. The next year Ali and Kumar (1994) considered the interactions between firm characteristics and the magnitudes of the financial statement effects of an accounting decision are considered. It was expected that including interactions would both enhance the ability to explain accounting choice and facilitate distinction between omitted variables and hypothesized relations. Results were consistent with these expectations.

Also in 1993 Harper and Strawser examined whether the requirements of SFAS 87 result in increased funding of corporate pension plans to counteract possible adverse perceptions of users about these plans. The results indicated that early adopters (companies adopting SFAS 87 in 1985 and 1986) increased the funding of their defined benefit pension plans in response to SFAS 87; however, later adopters did not do so. The findings provided evidence that companies may alter economic policies when faced with significant changes in financial disclosure requirements.

Rollings and Welsh (1994) compared FAS 36 and SFAS 87 disclosures. Details of changes in actuarial assumptions were not reported under FAS 36; however, the aggregate effect of the changes on income was disclosed and was often material. Under SFAS 87, companies have to provide information on the discount rate, compensation rate, and rate of return, which allows the financial statement user to determine if companies are using common assumptions and whether an assumption is unrealistic. One of the major shortcomings of SFAS 87 disclosures is the lack of information on the effect of assumption changes on future cash flows. Companies had never had to disclose the amount of cash contributed to the plan, but under APB Opinion No. 8, that was not a problem because most companies indicated they funded an amount equal to pension expense. That seemed less likely under SFAS 87, which 
restricts the choice of actuarial method for expense determination, but corporate disclosures are not adequate to determine funding policy.

A timing study by Tung and Weygandt (1994) extended the research on the positive (or economic consequences) theories of accounting choice by examining the characteristics of companies that chose to adopt SFAS 87 early (in fiscal year 1985 or fiscal year 1986). The analysis focused on the potential for 20 contracting costs in the form of bond covenant limitations on leverage and interest coverage as related to early adoption. Results generally supported the debt contracting hypotheses that early adopters tended to have higher leverage and a higher income effect from adopting SFAS 87 and a lower interest coverage ratio and a larger increase in this ratio from the adoption.

Blankley and Swanson (1995) made a longitudinal study of SFAS 87 pension rate assumptions. Amid allegations of widespread abuse in the business press, an investigation was presented of the reliability of three rate estimates required under SFAS 87 - the discount rate, expected rate of return on plan assets, and expected rate of future compensation - over the seven-year period 1987-1993. Expected rates of return change infrequently - consistent with the SFAS 87 requirement that they reflect long-run investment expectations. Although expected rates of return exceeded discount rates in every year, they tended to match actual rates of return over time. Lastly, no support was found for press allegations of a relationship between employer pension contributions and SFAS 87 rate choices.

In 1995 Stone, Joy and Thomas surveyed financial analysts and found they preferred pension plan accounting that contrasts with requirements of FAS no. 87. The preferred model included:

- Plan assets and accumulated benefit obligations are on the balance sheet.

- Prior service cost is recognized in the year of plan adoption or amendment.

- Gains and losses are recognized when they occur.

Annual pension expense is computed by netting the change in fair value of plan assets, deposits to the pension plan, and the change in accumulated benefit obligations.

On a different approach, Amir and Benartzi (1996) identified and tested motives for corporate pension asset allocations using a proprietary asset allocation database covering the 1988-1994 period. It focused on the question of whether the recognition of additional 
minimum pension liability in accordance with FAS No. 87 affects asset allocation. Results were consistent with the claim that companies allocate their pension assets to avoid the recognition of an additional minimum liability. In particular, companies that are close to the recognition threshold preferred fixed-income investments rather than equity investments. By investing in fixed-income securities, firms increase the correlation between pension assets and liabilities, reducing the likelihood of a pension deficit. Results also suggested that firms allocate their pension assets between equities and fixed-income investments to reduce the volatility of pension contributions.

In 1999 Asthana examined the effects of firms' financial and pension profiles in their funding strategies and actuarial choices. The paper uses reports filed by individual pension plans with the DOL under the requirements of ERISA for the analysis. Evidence shows that as firms become overfunded, they make conservative actuarial choices to avoid visibility costs, and that as firms become under funded, they make liberal actuarial choices to avoid visibility costs. The debiasing method developed in the paper can provide investors and creditors with the tools to identify the discretionary components of pension liabilities and thereby value firms more efficiently.

From the above summary of some of the research undertaken on the usefulness and means by which investors and the market utilise information concerning pension plans, it can be seen that most research has been undertaken in the United States where companies are required to report changes in the pension assets and liabilities. Applying the findings of this research to the New Zealand situation as already described suggests that, at a minimum, both current and future investors would be better served by improved requirements for full and detailed disclosures concerning any pensions schemes sponsored by the reporting entity. It may also be useful to consider whether or not the requirements of the new UK FRS 17 can, in some way, be extended to apply to New Zealand entities.

\section{Conclusion}

Accounting promulgations in the United States, United Kingdom and the International

Accounting Standards Committee all require that the company sponsoring the scheme show any surplus or liability in its own financial report. Disclosures in the financial reports of listed companies in New Zealand are scarce; half a page from a company complying with Australian note disclosure requirements, but otherwise not much else. Prior to 1997, there was little way of shareholders or auditors knowing if more disclosure or recognition was 
warranted. However, since the 1997 Amendment to the Financial Reporting Act this lid has been lifted. Superannuation schemes that are open to new members are deemed issuers and have to file their financial statements at the Companies Office. Result: surprisingly few companies continue to offer defined benefit schemes to their employees; most active superannuation schemes in New Zealand are now defined contribution schemes, where there is not the same potential for problems with unfunded and undisclosed liabilities. The defined benefit schemes show some variation in compliance with FRS 32. There is not the same problem with undisclosed deficits as has been observed in other jurisdictions.

Although this research has been restricted to defined benefit schemes, we now have the list from all the Companies Offices of all schemes that file at the different locations, and any interest in parallel studies of defined contribution schemes would be facilitated by these data already obtained. There are a number of different issues that arise with defined contribution schemes, but they are increasingly important for the investing public in New Zealand as defined benefit schemes appear to take a route to near-extinction. Nevertheless, the movement of information concerning defined benefit schemes (as already described in this paper) into the public domain presents regulators with a useful opportunity to review reporting requirements for such entities and their sponsoring companies.

\section{References}

Abraham, B. 1999. "Superannuation and the battle of the tax acronyms". The Independent 18/8/99:11-30.

Ali, A and Kumar, K. R. 1993. "Earnings management under pension accounting standards: FAS 87 versus APB 8." Journal of Accounting Auditing and Finance, 8(4): 427 - 446

1994 "The magnitudes of financial statement effects and accounting choice: the case of the adoption of FAS 87'. Journal of Accounting and Economics 18(1): 89 - 114.

Amir, E and S Benartzi 1996 "Accounting recognition and the determinants of pension asset allocation”. Journal of Accounting Auditing and Finance 14(3): 321 - 343

1998 "The expected rate of return in pension funds and assets allocation as predictors of portfolio performance". Accounting Review 73(3): 335 - 352. 
Ang, N., G. Gallery, and B. K. Sidhu. 1999 "The value relevance of superannuation disclosures by

Australian-listed firms sponsoring defined benefit plans". Accounting and Finance 3: 205 228.

Anon. 1998. "FRS-32 approved". Chartered Accountants Journal of New Zealand, 77(4): 43.

Asthana, S 1999 "Determinants of funding strategies and actuarial choices of defined-benefit pension plans" Contemporary Accounting Research, 16: 39 - 74.

Barth, M. E. 1991. "Relative measurement errors among alternative pension asset and liability measures". The Accounting Review 66(3): 433-463.

Barth, M., Beaver, W. H. and Landsman, W. R. 1992. "The market valuation implications of net periodic pension cost components". Journal of Accounting and Economics 15: 27 - 62.

Baskerville, R. 1993. "Superannuation reporting - Incomparable and inconsistent". Accountants' Journal. 72(11): 69-72.

Benovitz, D. M. 1994. "Is your pension plan worth less than you think?" Financial Executive, Jan/Feb: 30-33.

Blankley, A. I. and E. P. Swanson. 1995. A longitudinal study of FAS 87 pension rate assumptions. Accounting Horizons 9(4): 1-21

Brorstom, B 1998 “Accrual Accounting, Politics and Politicians”. Financial Accountability and Management 14: 319 - 334.

Carpenter, B. W. and Mahoney, D. P. 1992. The enduring controversy over pension accounting: are current measures of pension assets and liabilities misleading? Journal of Applied Business Research 8(4): 30 - 48

Clark, P. 1998. "Counting the cost of pensions". Accountancy 121 (1255): 70-71

Clinch, G. and T Shibano. 1996 "Differential tax benefits and the pension reversion decisions" Journal of Accounting and Economics 21: 69 - 106

Daly, L. A. 1984. The Valuation of Reported Pension Measures for firms sponsoring defined benefit plans. The Accounting Review 59(2): 177 - 198. 
Davis-Friday, P. Y., L. B. Folami, C. S Liu, H. F. Mittelstaedt. 1999 "The Value Relevance of Financial Statement Recognition vs. Disclosure: Evidence from FAS No. 106". Accounting Review 74(4): 403- 423.

Ellner, S. H. 1996. "New disclosures for underfunded defined benefit plans". The CPA Journal. 66(5): 62.

Espahbodi, R. and M. M. Haver. 1996 "On the Robustness of the Results of Adoption Date Choice Studies: The Case of Pension Accounting" Review of Quantitative Finance and Accounting

Estey, N. A. 1999. “Accountable for your promises”. CA Magazine 132(3): 39-40.

Familton, K. 1993. "Scheme amendments - no easy matter". Accountant's Journal Sept: 5053.

FASB 1981. Discussion Memorandum: An Analysis of issues related to employers' accounting for pensions and other post employment benefits. Stanford: FASB.

Ferris, K P and A. H Chen. 1997. "Evidence on the Timing and Determinants of Overfunded Pension Plan Termination" Review of Quantitative Finance and Accounting

Fogarty, T. J. and J. Grant. 1995. Impact of the actuarial profession in financial reporting Accounting Horizons 9(3): 23 - 33.

Francis, J. R. and Reiter, S. A. 1987. Determinants of Corporate Pension Funding Strategy. Journal of Accounting and Economics 9: 35 - 59.

Fulman, Ricki. 1999. "Analysts discount those surplus-added earnings". Pensions and Investment Age. 27(20): 6, 73.

Gopalakrishnan, V., and T. F. Sugrue. 1992. Economic Consequences of pension policy deliberations (FAS No. 87): An empirical assessment of debt-covenant hypothesis. Journal of Business Finance and Accounting. 19(5): 751-775.

1993 An empirical investigation of stock market valuation of corporate projected pension liabilities. Journal of Business Finance and Accounting. 20(5): 711-724 Hall, T. 1999. "Facing the Superannuation Dilemma”. Chartered Accountants Journal, Nov. 48. 
Hamdallah, Ahmed, E-S, and Ruland, W. 1986. The Decision to Terminate Overfunded Pension Plans. Journal of Accounting and Public Policy 5: 77-92. 23

Harper, R M. and Strawser, J. R. 1993. The effect of FAS 87 on corporate funding of defined benefit pension plans. Journal of Business Finance and Accounting 20(6): 815-833.

Harper, R M., Mister, W G and Strawser, J. R. 1987. The Impact of New Pension Disclosure Rules on Perceptions of Debt. Journal of Accounting Research 25(2): 327 - 330.

1991 The Effect of Recognition Versus Disclosure of Unfunded Postretirement Benefits on Lenders' Perceptions of Debt. Accounting Horizons. 5(3): 50-56.

Harper, R M., Mister, W G, Strawser, J. R. and Summers, G. E. 1990. Pension Disclosures and Internal Auditors' Perceptions of Debt. Internal Auditing. 5(3); 34 - 39

Heath, P. R. and J. K. Maxton. 1997. "Superannuation schemes and insolvency". NZ Business Law Quarterly 3: 43-69.

Lander, G. H., Reinstein, A., and Fosu, A. K. 1991. An evaluation of agency theory influence in pension accounting. Journal of Applied Business Research. 8(1): 13 - 16.

Landsman, W. 1986. "An empirical investigation of pension fund property rights". The Accounting Review 61: 662-691.

Laswad, F. and R. Baskerville. 1995a. "Financial reporting by superannuation schemes". Chartered Accountants Journal of New Zealand. 74(1): 46-48.

1995b. "Superannuation schemes: Current practices". Chartered Accountants Journal of New Zealand. 74(2): 20-23.

Laswad, F. and Robertson, B. 1998. "Superannuation Standard 'fine-tuned"'. Chartered Accountants Journal 77(5): 33-35.

Lilien, Steven. 1999. Discussion: "Accounting Recognition and the Determinants of Pension Asset Allocation". Journal of Accounting, Auditing and Finance. 14(3): 344-346.

Luecke, R. W. and Andrzejewski, C. 1998. "FASB 132: What Companies must disclose" Journal of Accountancy, Sept: 43-49.

Mittelstaedt, H. F. and Reiger P R 1990 Further Evidence on Excess Asset Reversions and Shareholder Wealth. Journal of Risk and Insurance. 57(3): 471-486. 
1993. The market response to pension plan terminations. Accounting Review.

68(1): 1-27.

Mittelstaedt, H. F. 1989. An empirical analysis of the factors underlying the decision to remove excess assets from overfunded pension plans. Journal of Accounting and Economics 11: 399-418.

Morris, R. C. 1976. Reporting the Financial Affairs of Pension Funds. International Centre for Research in Accounting, Occ. Paper No. 10.

Ndubizu, G. A., Y. C. Choi, and R. Jain. 1993. Corporate lobbying strategy and pension accounting deliberations: An empirical analysis. Journal of Accounting, Auditing and Finance 8 (3): 277-287.

Pinfold, G. 1995. "FRS-32: What are the bean counters up to?" Superbenefits, October: 33, $40-43$.

Pontiff, J., Shleifer, A and Weisbach, M. S. 1989. Reversions of excess pension assets after takeovers. Rand Journal of Economics 21: 600 - 613

Power, T. 1997. "Super: nest egg turns into minefield". Australian Accountant, February: 1215. 24

Robertson, B. 1998. "Superannuation Standard revised". Chartered Accountants Journal 77(4): 54-55.

Rollings, T. P., and Welsh, M. J. 1994. Changes in pension plan actuarial assumptions: a comparison of FAS 36 and FAS 87 disclosures. Journal of Pension Planning and Compliance 20 (1): 67-79

Ross, M. 1999. Casebook: Pension Funds. Chartered Accountants Journal 78(3): 70.

Sami, H., and Welsh, M. J. 1992. Characteristics of early and late adopters of pension accounting standards FAS No. 87. Contemporary Accounting Research 9(1): 212 - 236.

Schultz, E. E. 1999a. Overfunded Pension Plans fatten companies' earnings. The Wall Street Journal 15.6.99 1999b. Pension Terminations Become Temptations for Some Employers. The Wall Street Journal 15.6.99 
Scott, T W 1991 Pension Disclosure Under FAS No. 87: Theory and Evidence. Contemporary Accounting Research. 8(1): 62-81.

1994 Incentives and Disincentives for Financial Disclosure: voluntary disclosure of defined benefit pension plan information by Canadian firms. Accounting Review. 69(1): 26-43.

Selling, T I and Stickney C P. 1986. Accounting Measures of Unfunded Pension Liabilities and the Expected Present Value of Future Pension Cash Flows. Journal of Accounting and Public Policy. 5(4): 267-285.

Stone, M. 1987. A Financing Explanation for Overfunded pension plan terminations. Journal of Accounting and Economics 25(2): 317 - 326.

Stone, M.S. 1982. A survey on research on the effects of corporate pension plan sponsorship: implications for accounting. Journal of Accounting Literature 1: 1-31.

Stone, M.S., D. W. Joy and C. J. Thomas. 1995. Opinions of Financial Analysts on accounting for defined benefit plans. Journal of Applied Business Research 11(3): 65 - 73.

Thomas, J. 1989. Why do firms terminate overfunded pension plans? Journal of Accounting and Economics 11: 361 - 398.

Thornton, E. 1999. The Secrets Pour Out. Business Week 3640: 20 - 23.

Todd Task Force. 1992. Private Provision for Retirement - The Options. Report of the Task Force on Private Provision for Retirement. Wellington: Government Printer.

Tung, S. S. and Weygandt, J. J. 1994. The determinants of timing in the adoption of new accounting standards: a study of FAS No. 87, Employers' Accounting for Pensions. Journal of Accounting, Auditing and Finance 9(2): 325 - 337

Whitehead, M. 1999, "Firms 'massaging' figures to mask pension shortfalls". People Management 5(19): 